\title{
Macroeconomic shocks and policy reforms: \\ lessons from the 1999 downturn in Chile
}

\author{
Julio J. Guzmán
}

\begin{abstract}
This article analyses the Chilean government's response to the 1999 recession that followed on from the Asian financial crisis, focusing on the macroeconomic policy reforms adopted and the institutional factors that influenced this response. The analysis is based on a review of previous research on the topic and suggests that some fiscal and monetary policies adopted during 1997-1998 exacerbated the effects of what were initially external shocks. However, fiscal discipline and the robust public institutions developed before and after the recession strengthened Chilean social protection policies. Specifically, public debt reduction in the 1990s, the Copper Revenue Stabilization Fund (FEC) set up in 1985, the structural surplus fiscal rule introduced in 2000 and the new monetary, exchange-rate and fiscal policy mix of that decade reduced the vulnerability of Chile to new shocks.
\end{abstract}

\section{Keywords}

Economic conditions, economic recession, macroeconomics, economic policy, public expenditures, fiscal policy, economic indicators, Chile

\section{JEL classification}

H53, J21, J48

\section{Author}

Julio J. Guzmán is an assistant professor at the School of Government of Adolfo Ibáñez University, Santiago, Chile. Email: julio.guzman.c@uai.cl. 


\section{Introduction ${ }^{1}$}

Chile has been singled out as the leading exemplar of a successful transition to sustained growth in Latin America (Ffrench-Davis and Machinea, 2007). This achievement has been the consequence of economic reforms and macroeconomic policies that have controlled inflation and smoothed economic cycles (OECD, 2015). Thus, the main assets of the Chilean economy are its fiscal discipline, low inflation, considerable trade openness, solid financial system, high institutional quality and good infrastructure (De Gregorio, 2005). ${ }^{2}$

These economic assets are the result of a learning process that has included both successes and failures in the implementation of government policies. For example, the 1982-1983 crisis, which was associated with macroeconomic disequilibria, generated consensus among political actors about the importance of maintaining fiscal sustainability during the democratic governments of the 1990s (Arellano, 2005).

In this context, the present article assesses the Chilean experience in coping with the 1999 recession triggered by the Asian financial crisis, focusing on the macroeconomic policies adopted and the institutional factors that influenced the government policy response to the recession. ${ }^{3}$ The purpose of the exercise is to highlight the strengths and weaknesses of the learning process Chile went through during the late 1990s and early 2000s, which influenced macroeconomic policies that are still in place. In this way, it is possible to provide insights for other countries' policy reforms and to disseminate crosscountry lessons about government responses during recessions. The analysis is based on a review of previous research on this topic, focusing primarily on Chilean studies.

Chile suffered a severe change in external conditions during 1998. The Asian crisis reached global proportions, reducing capital inflows into Chile to one third of what they had been in 1990-1997. Likewise, the country's terms of trade decreased by $12.5 \%$ in 1998, the result being a current account deficit that peaked at $6.5 \%$ of gross domestic product (GDP) in the third quarter of that year.

Our review of previous research suggests that the adjustment policy adopted by the Chilean authorities during 1998 exacerbated the effects of these initial external shocks. There was a lack of coordination between fiscal and monetary policy, with the monetary adjustment coinciding with an expansionary fiscal policy. Thus, the burden of adjustment fell almost exclusively on monetary policy (Corbo and Tessada, 2003). In addition, there were overblown concerns that high pass-through from depreciation to inflation would jeopardize the inflation target for the following year. This led to a disproportionate monetary adjustment and thence to an illiquidity episode that induced contractionary effects in the economy during 1998 in excess of what was necessary to adjust domestic expenditure. A degree of labour market inflexibility and a three-year plan of increases in the minimum wage intensified the unemployment effects of the initial shocks and the macroeconomic policies adopted. Overall, this resulted in negative GDP growth of $-0.8 \%$ in 1999 , the first year with negative growth since the Latin American debt crisis of 1982-1983, and an increase in the unemployment rate from $6.1 \%$ in 1997 to $9.7 \%$ in 1999.

\footnotetext{
1 The author would like to thank an anonymous referee for valuable comments. He is also grateful to Emanuele Baldacci, Polly Jones, Andrew Mason and Truman Packard for helpful comments on a previous version of this paper and to Maris Goldman, Thomas Marhoefer, Divya Mathur, Kathryn McLellan, Claudio Montenegro and Heidi Smith for their assistance. Any remaining limitations and errors in the text are entirely the author's own.

2 However, the Chilean development model has prompted some concerns regarding its ability to deliver inclusive growth and provide support to the critically vulnerable (see, for example, Contreras, 2009; Mayol, 2012; Atria and others, 2013; Atria, 2014).

3 This paper analyses the 1999 downturn triggered by the Asian financial crisis rather than the more recent 2008 financial crisis (the Great Recession) because this allows the long-term sustainability of the Chilean reforms adopted thereafter to be reviewed, whereas the consequences of the 2008 crisis and the subsequent European crises are ongoing.
} 
Although the adjustment policy adopted during the 1999 recession can be judged inappropriate with hindsight, the fiscal discipline and sound public institutions implemented before and (especially) after the recession strengthened Chilean social protection policies. In particular, this paper identifies four key factors that positively affected Chile's ability to deal with the effects of the 1999 downturn: (i) public debt reduction during the 1990s, (ii) the Copper Revenue Stabilization Fund (FEC) set up in 1985, (iii) the structural surplus fiscal rule of 2000, (iv) the new monetary and fiscal policy mix of the twenty-first century and (v) the preparatory measures adopted by the central bank prior to implementing the free-floating exchange-rate system. This new policy framework allowed a countercyclical fiscal policy to be implemented during 2000-2003 and the last financial crisis (the Great Recession).

This article discusses three key factors that affected the country's ability to scale up social protection programmes during the crisis: (i) a lack of systematic interaction between programmes and duplication of functions and objectives, (ii) inadequate installed administrative capacity before the crisis to manage employment programmes and (iii) inertia in fiscal expenditures committed before the crisis.

The rest of the paper is organized as follows. Section II summarizes the nature and macroeconomic consequences of the 1999 downturn. Section III presents an assessment of government policy responses during the recession, including macroeconomic policies, fiscal expenditure and employment programmes. Section IV describes the institutional factors that affected the country's ability to scale up social protection programmes during the recession. Section $\mathrm{V}$ concludes.

\section{The 1999 downturn: causes and consequences}

In 1998, the external conditions faced by Chile changed profoundly from those of previous years. The Asian crisis initially affected emerging Asian economies but later attained global proportions, spreading to Russia and the Latin American countries. This international financial crisis abruptly reduced capital inflows into Chile from an average of $6.8 \%$ of GDP in $1990-1997$ to $2.5 \%$ of GDP in 1998 (see table 1).

Simultaneously, international markets for Chile's main exports were being affected by lower growth in Asian economies. Chile's terms of trade declined by 12.5\% during 1998. Overall, the Chilean economy faced particularly severe external conditions after the onset of the Asian crisis, forfeiting resources equivalent to $6.2 \%$ of GDP in 1999 as a consequence of the combined effect of the decline in the terms of trade, the fall in export volumes and the reduction in capital inflows (see the External Conditions Index in table 1).

These negative external conditions coincided with overheating in the domestic economy owing to a large expansion of domestic expenditure in 1997. In the first quarter of 1998, for example, domestic expenditure growth was nearly double GDP growth (12.8\% versus 6.8\%). Consequently, the current account deficit peaked at $6.5 \%$ of GDP in the third quarter of $1998 .{ }^{4}$

\footnotetext{
4 Although monetary policy centred on an inflation target, it was also aimed at controlling the size of the current account deficit. Unlike other independent central banks, the Central Bank of Chile is also responsible for the exchange-rate system and exchange-rate policy.
} 


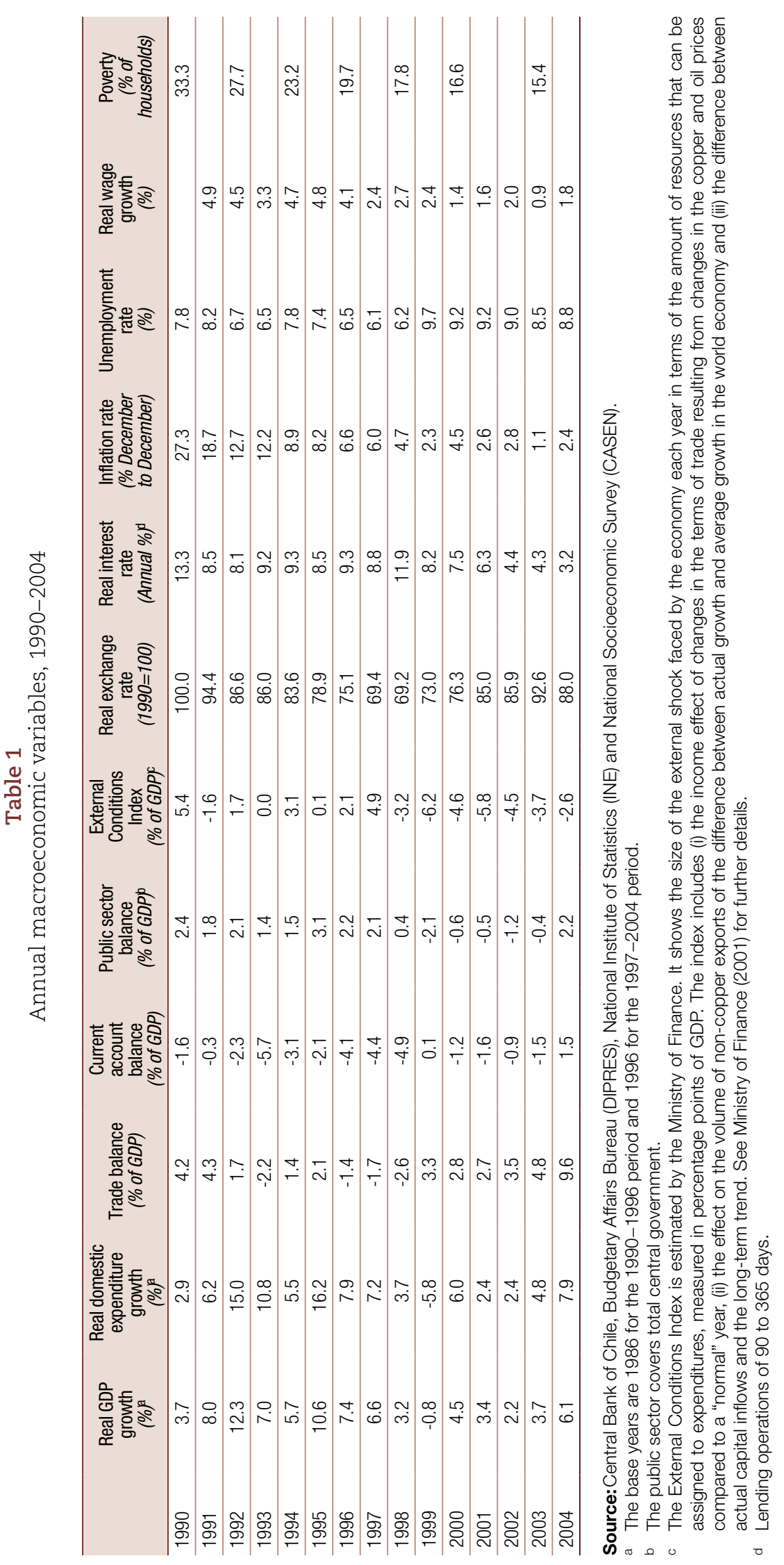


In addition, several speculative attacks on the currency took place as a consequence of contagion from the external crises to Latin American markets. The central bank chose to defend the exchange rate to prevent depreciation. However, the monetary adjustment interacted with an expansionary fiscal policy in such a way that monetary and fiscal policy operated at cross-purposes (Corbo and Tessada, 2003). The adjustment was therefore achieved mostly by a more restrictive monetary policy, resulting in an excessive monetary adjustment that led to an illiquidity episode at the end of 1998.

The external shocks and the 1998 illiquidity episode induced contractionary effects in the economy beyond what was necessary to adjust domestic expenditures. There was an excessive reaction in GDP and the employment rate. After peaking in early 1998, GDP and domestic expenditure (private and public consumption plus total investment) started to decrease rapidly after the adjustment policies were adopted. The annual GDP growth rate declined by more than 10 percentage points in just 12 months, from $8.2 \%$ in the fourth quarter of 1997 to $-2.3 \%$ in the fourth quarter of 1998 . By the end of the third quarter of 1998 , the high interest rates of the previous months had contributed to a sharp contraction in domestic spending that greatly reduced the current account deficit.

Economic activity bottomed out in the second quarter of 1999, with GDP down by $4.1 \%$ and domestic expenditure by $10.1 \%$ year on year. The economy thus had four consecutive quarters of negative GDP growth (fourth quarter of 1998 to third quarter of 1999), ending 1999 with a rate of $-0.8 \%$. This was the first year of negative growth since the Latin American debt crisis of 1982-1983. The greatest declines were in private consumption and fixed investment (Corbo and Tessada, 2003). Investment growth was negative for five quarters (from the fourth quarter of 1998 to the fourth quarter of 1999), with the four-quarter rate falling as low as $-25.6 \%$ in the second quarter of 1999 .

Unemployment began to rise in late 1998, peaking at $11.3 \%$ in the third quarter of 1999 . It then started to decline slightly, but with large seasonal fluctuations. The average unemployment rate rose from $6.8 \%$ during 1994-1998 to 9.7\% in 1999. In 2004, six years after the beginning of the slowdown, unemployment was still above the 1990-1997 average despite the pick-up in growth since the end of 2003. The new adverse external conditions faced by Chile in 2001-2002 (see table 1) are also likely to have affected the recovery in employment. ${ }^{5}$

Table 1 also shows the evolution of the real wage index. It can be seen that real wage growth averaged $1.8 \%$ annually over 1999-2001, 1.9\% less than the average in the previous five years (3.7\% over 1994-1998). On the other hand, the decreasing trend in inflation since 1990 continued, with prices rising by $2.3 \%$ in 1999 as compared to $4.7 \%$ the previous year. The strong defence of the nominal exchange rate by the monetary authorities and the reduction in domestic spending pressure continued to bear down on inflation, taking it lower than desired or expected in 1999.

The more expansionary domestic policies adopted in 1999, along with a gradual improvement in the external environment, brought on a rapid recovery of economic activity in the latter part of the year.

Overall, while the economic effects of the 1999 recession were moderate and transitory, social impacts such as unemployment lasted longer. In fact, it took only one year for GDP per capita to return to its pre-recession level (measured in both real terms and in Chilean currency), whereas the unemployment rate remained consistently above its pre-recession level.

\footnotetext{
5 External conditions for the Chilean economy deteriorated in 2001-2002 because of an abrupt slowdown in economic activity in the developed countries and a decline in global trade, aggravated by the terrorist attacks of 11 September 2001.
} 


\section{The government policy response}

\section{Macroeconomic policies adopted after the initial shocks}

The combination of severe external shocks and a burgeoning current account deficit in 1998 forced the Chilean authorities to adopt an adjustment policy in order to correct the expenditure path. However, the fiscal and monetary policies adopted after the shocks were uncoordinated, with the period of adjustment coinciding with an expansionary fiscal policy (Corbo and Tessada, 2003).

The fiscal budget for 1998 was planned on the assumption that GDP growth would rise to $7 \%$, but in the end it was 3.2\%. Although the authorities retrenched fiscal expenditure three more times during 1998 (Budgetary Affairs Bureau, 1999), the burden of adjustment fell almost exclusively on monetary policy. Furthermore, during 1998 the authorities raised public sector wages by 6\% and introduced a three-year plan of annual increases of over $10 \%$ to the nominal minimum wage. These measures made policy switching more difficult and costly in terms of unemployment.

Monetary policy faced a trade-off between the inflation target and the downturn in real activity. After the speculative currency attacks, the central bank was awkwardly placed but opted to defend the exchange rate and not allow a currency depreciation. However, there were overblown concerns that a rapid depreciation of the peso would endanger the inflation target. The central bank thus started to sell foreign reserves and, in January 1998, to increase the policy interest rate. As the external environment worsened and the expectation of depreciation increased, the market interest rate rose far above the policy interest rate, seriously affecting financial market liquidity. In fact, the overnight annual interest rate reached its highest values of the decade, exceeding 23 percentage points in September 1998 (see figure 1).

Figure 1

Market interest rate and policy interest rate, 1997-2000

(Percentage annual overnight interbank rates)

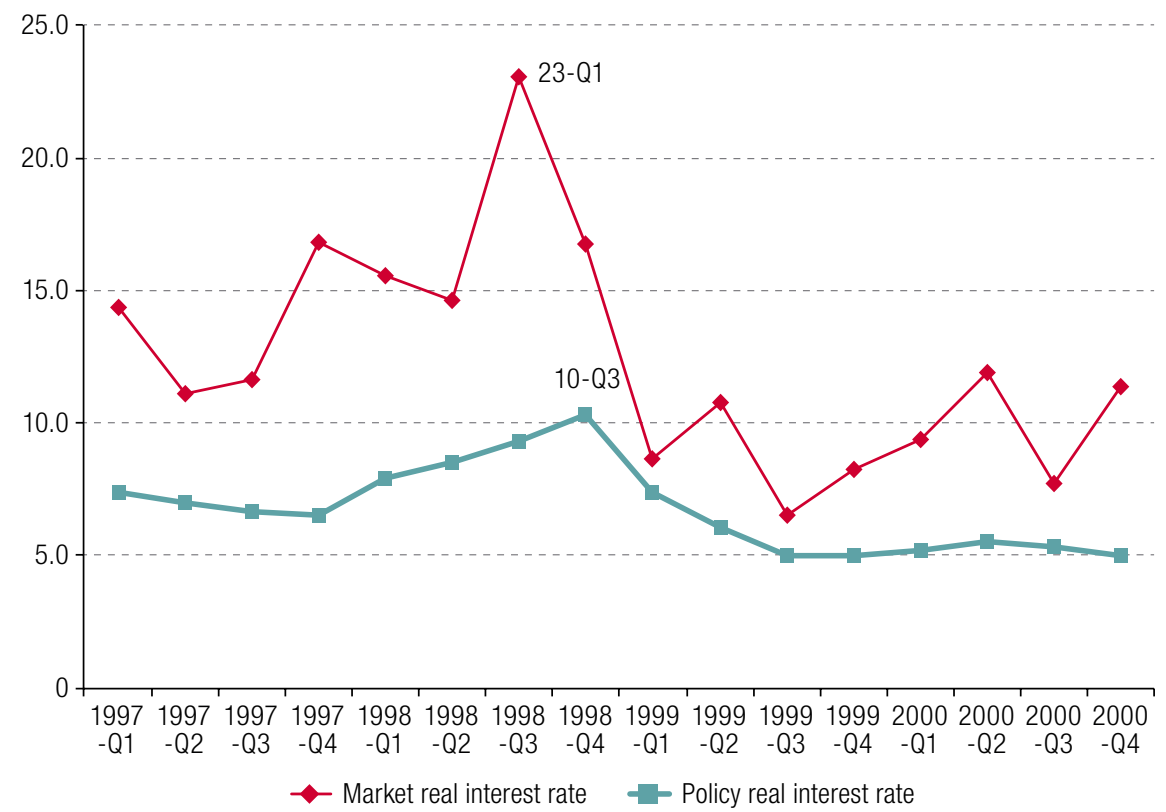

Source: Central Bank of Chile. 
The decline in Russia's economy and increasing pressure on the Brazilian currency provoked two new speculative attacks against the peso in June 1998 and August 1998. Following these, the central bank adopted additional measures that included narrowing the exchange-rate band, reducing the reserve requirements for capital inflows and raising the policy interest rate to 14\% in September 1998 in order to be able to exert some control over the setting of the market interest rate. ${ }^{6}$

In 1999, when it became clear that the domestic expenditure reaction had overshot, the authorities began to reorient monetary and fiscal policy towards an expansionary cycle. During 1999, the central bank reduced the policy interest rate several times and fiscal expenditure grew by $4.5 \%$, which was $5.3 \%$ more than GDP in the same period (-0.8\%).

There is evidence that the adjustment policy response exacerbated the effects of the external shocks of 1998 (Corbo and Tessada, 2003). The 1998 illiquidity episode had contractionary effects in the economy beyond what was necessary to adjust domestic expenditures. This severely affected private sector investment and consumption decisions and had prolonged effects on unemployment.

With the expectation of a further rise in the current account deficit, the appropriate response would have been a monetary and fiscal policy mix aimed at moderating spending while facilitating the real depreciation required for switching. Given that the exchange rate was already at the stronger end of the target band, the correct mix would have been a restrictive fiscal policy and a monetary policy geared towards supporting nominal and real depreciation of the currency. A more restrained fiscal budget for 1998 and smaller wage increases might have helped to adjust domestic spending without exclusive reliance on monetary policy (Corbo and Tessada, 2003). ${ }^{7}$

Rigid exchange-rate policies without the option of an independent monetary policy may enhance credibility, but they can also make adjusting to shocks more painful when labour markets are inflexible or fiscal policy is inadequate (De Ferranti and others, 2000). This is true of Chile's initial policy response to the turbulent 1997-1998 period. The defence of the exchange rate against the speculative attacks of 1998 preserved the credibility of monetary policy. However, the authorities' inability to achieve a balanced mix of monetary and fiscal policies, along with some inflexibility in labour markets, entailed a costly adjustment to the shocks in terms of unemployment.

Chile began to move towards a new monetary and fiscal policy mix in the second half of 1999. In September that year, the central bank redefined its inflation target, announcing that the new objective was to keep annual inflation within the range of $2 \%$ to $4 \% .{ }^{8}$ At the same time, it replaced the exchangerate band system with a floating rate. This was aimed at giving the central bank more autonomy to conduct monetary policy and to confront external shocks, including changes in external terms of trade and interest rates. Finally, in 2000, the government introduced a fiscal rule based on a structural surplus of $1 \%$ of GDP to reaffirm its commitment to fiscal responsibility. ${ }^{9}$

Unlike other countries that underwent upheavals in the switch from a fixed to a floating exchange-rate system (e.g. Brazil in 1999 and Uruguay in 2002), Chile had a mostly orderly transition to a floating regime. It was not a sudden change in the way exchange-rate policy was conducted. On the contrary, during much of the 1990s the exchange-rate band mimicked exchange-rate flexibility, with the parameters being shifted to validate market pressures (Morandé and Tapia, 2002). The

\footnotetext{
6 See Corbo and Tessada (2003) for further details of the measures adopted.

7 De Gregorio and Tokman (2005) even claim that there were no reasons to stay within the exchange-rate band in 1998, arguing that, given the sequence of external shocks, moving faster towards a fully flexible exchange-rate regime would have smoothed the adjustment costs faced by the Chilean economy during the 1999 downturn. On the other hand, Morandé and Tapia (2002) argue that departing from the band during the 1998 attack on the peso could have led to an exchange-rate overreaction, inducing real negative effects.

8 Previously, beginning in 1994, the central bank had set a point estimate for inflation each year.

9 See section IV for further details of the new fiscal rule.
} 
crawling band was widened over time in response to increases in capital inflows and to changing economic conditions and policy priorities until it was finally abolished in 1999 (Duttagupta, Fernández and Karacadag, 2005; Ötker-Robe and others, 2007).

This gradual transition prevented the negative real effects that could have been caused by an exchange-rate overreaction. ${ }^{10}$ Morandé and Tapia (2002) show that the Chilean experience following adoption of a flexible exchange rate was relatively calm. Core inflation remained close to the steady-state target with low pass-through from changes in the exchange rate to domestic inflation. Exchange-rate volatility increased only marginally by international standards. Likewise, exchange-rate liberalization did not lead to any severe currency mismatches in the private sector that could have caused balance-sheet effects and financial distress.

These positive results were due to some favourable preconditions present before the fixed-tofloat shift and to the preparatory measures adopted by the central bank prior to floating. The favourable preconditions included several elements already in place before 1999: central bank independence and accountability, a central bank mandate to follow an explicit inflation target as its primary objective, limited dollarization of the banking system (by contrast with the early 1980s) and a well-developed and regulated financial sector. The preparatory measures included, among others, the strengthening of currency mismatch regulations, liberalization of derivatives markets and liberalization of capital inflows (see section IV.1(e) for further analysis of the preparatory measures adopted).

\section{Fiscal expenditure and emergency employment programmes}

The new monetary and fiscal policy mix implemented in 1999 permitted the pursuit of a countercyclical fiscal policy during 2000-2002 even as interest rates were kept substantially low. Figure 2 illustrates this point. Its primary axis shows the evolution from 1996 to 2005 of total fiscal expenditure, social protection expenditure and unemployment expenditure as percentages of GDP. Social protection expenditures are the main category of fiscal expenditure. Unemployment expenditure is one of the items within this category and includes spending on emergency employment programmes. All three ratios are measured relative to their respective values in $1996(1996=100)$ to give a picture of their evolution over time.

The chart shows that fiscal expenditures grew by more than GDP in 1998-1999, but the policy interest rate remained quite high during that period. In 2000-2002, by contrast, fiscal expenditures grew at the same rate as GDP while the policy interest rate steadily decreased over time. Thus, the authorities were able to increase the fiscal expenditure-to-GDP ratio by nearly $14 \%$ during $2000-2002$ as compared to the 1996 value while implementing a non-restrictive monetary policy.

As table 2 shows, the external conditions faced by the Chilean economy in 2000-2003 were similar in magnitude to the external conditions faced in 1982-1983. In 1982-1983, however, both GDP and public spending decreased substantially, affecting public investment and social expenditure severely. In 2000-2003, by contrast, GDP and public spending grew at 3.0\% and 4.2\%, respectively, which helped to reduce poverty and keep unemployment relatively low by comparison with the crisis of the 1980s.

\footnotetext{
${ }^{10}$ Calvo and Reinhart (2002) argue that the authorities usually have a "fear of floating", i.e. are reluctant to implement fully floating systems because of the possible negative effects of exchange-rate volatility on the financial system and firms' balance sheets.
} 
Figure 2

Fiscal expenditure by type and policy interest rate, 1996-2005

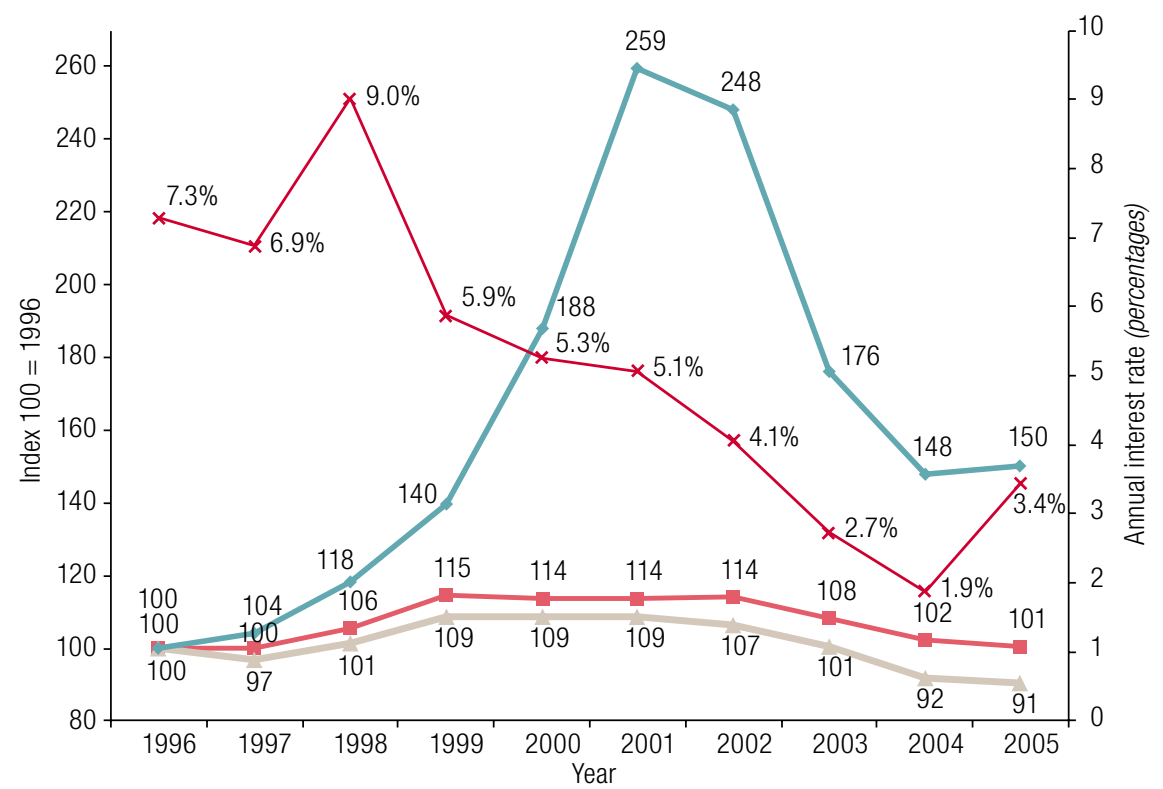

$*$ Policy real interest rate $\neg$ Unemployment expenditure $\rightarrow$ Total fiscal expenditure $\rightarrow$ Social protection expenditure

Source: Budgetary Affairs Bureau (DIPRES) and Central Bank of Chile.

Table 2

External shocks and their impacts, 1982-1983 versus 2000-2003

\begin{tabular}{lcc}
\hline & $1982-1983$ & $2000-2003$ \\
\hline External Conditions Index (percentages of GDP) & -4.1 & -4.4 \\
\hline GDP (percentage changes) & -8.5 & 3.0 \\
\hline Unemployment (percentage annual averages) & 19.1 & 8.9 \\
\hline Public spending (real percentage changes) & -2.1 & 4.2 \\
\hline Poverty (changes in percentage rates) & 15.0 & -1.8 \\
\hline
\end{tabular}

Source: Ministry of Finance, “Exposición sobre el estado de la hacienda pública 2004”, Santiago, 2004.

As a result, the new macroeconomic policy mix, and especially the fiscal policy rule, has attenuated the impact of external shocks on the economy and stabilized the financing of social policies. This was also true during the 2009 Great Recession. Thus, it has become a fundamental element of Chilean social protection policies.

The 2000-2002 countercyclical fiscal policy included a 9\% increase in the social protection expenditure-to-GDP ratio relative to 1996. This growth was led by unemployment expenditures, which had steadily increased since the substantial rise in unemployment of late 1998, growing two and half times as fast as GDP from 1996 to 2001-2002 (see figure 2).

Unemployment expenditure increased mainly because of a large escalation in emergency employment programmes during 1999-2002, namely the Employment Programmes with Fiscal Support. With the experience of the 1970s and 1980s as a precedent (see section IV), public employment programmes modestly re-emerged in 1992 when the new democratic government began a programme of job creation run by the municipalities. However, resources and coverage were modest. In response to the increase in unemployment during the second half of 1998, there was a new impetus to improve public employment programmes in 1999. This included, among other measures, budget reallocations to increase funding for such programmes. 
Before 1999, the installed administrative capacity for employment programmes was inadequate. This put considerable pressure on the public administration to respond rapidly to the urgent demands arising after the crisis, and the result was a swift expansion of the direct employment programmes already in operation. ${ }^{11}$ These programmes paid around the minimum wage. Overall, total coverage rose from about 10,000 jobs in April 1999 to a peak of 100,000 in November 1999 (see figure 3). The new government reduced the municipal programmes substantially in 2000 , so that by December that year coverage did not exceed 15,000 jobs.

Figure 3

Employment Programmes with Fiscal Support, 1999-2002

(Average jobs financed per month)

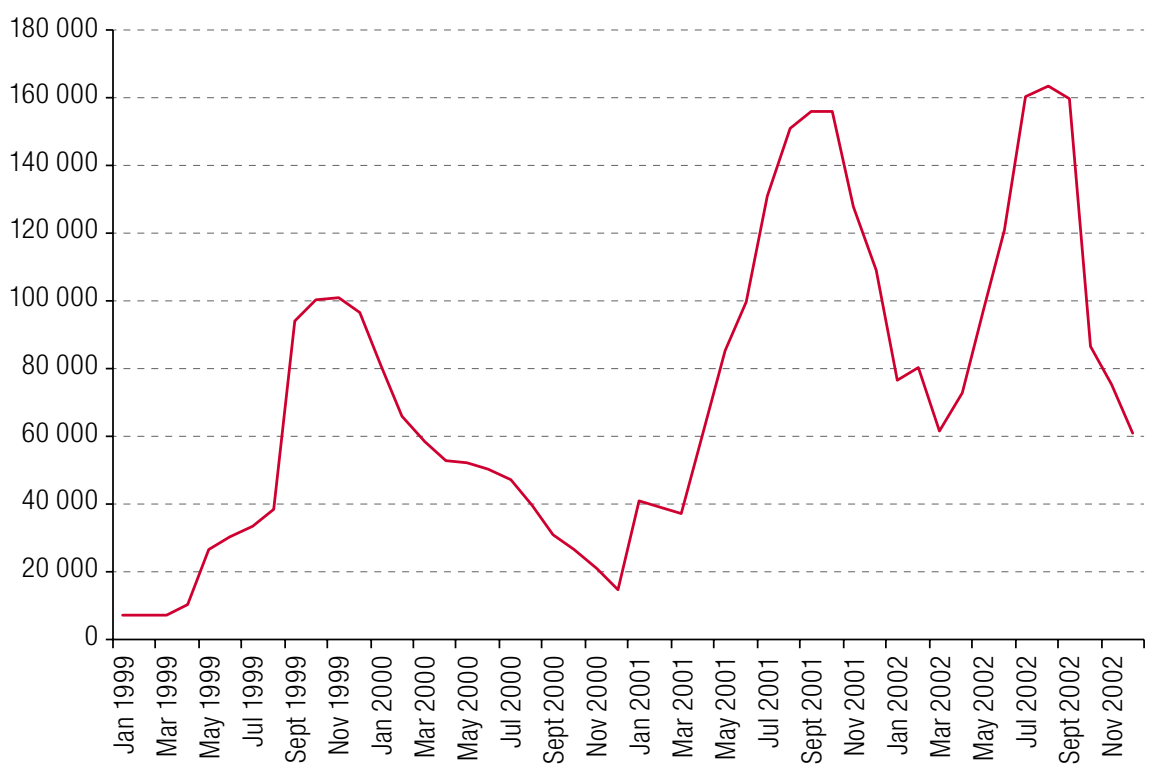

Source: Budgetary Affairs Bureau (DIPRES).

In summary, the government used municipalities to implement the first stage of the employment programmes (1999-2000). The basic idea was to provide temporary employment for workers who had lost their jobs. However, the programmes also drew in a large number of people who had previously been outside the labour force. The persistence of the downturn and the relatively attractive wages paid made it difficult to terminate positions in what were intended as temporary employment programmes.

The second stage of the employment programmes began in 2001 when the municipal schemes were reformulated and new programmes were created to bring flexibility to hiring and project execution. Indirect employment programmes, such as occupational training and time-limited subsidies for job creation in the private sector, were preponderant at this stage. ${ }^{12}$ The acceleration of investment in labourintensive public infrastructure projects was also used as an instrument to increase demand for labour during the downturn (Guzmán, 2016). This provided indirect support for employment by increasing the demand for (predominantly) unskilled labour as a consequence of the increased investment. Overall, the average number of jobs financed by all these programmes rose from 46,000 in 1999 to 100,000 in 2002, peaking in August 2002 at 163,000 (see figure 3), or nearly 3\% of the labour force at that time (Arenas and Guzmán, 2003).

\footnotetext{
${ }^{11}$ These programmes included the Employment Generation Programme (PGE) and the Programme for Urban Improvement and Communal Infrastructure (PMU).

12 Examples included the Solidarity and Social Investment Fund (FOSIS) Programme of Labour and Employment Relocation and the private sector employment subsidies provided by the National Training and Employment Service (SENCE).
} 
The flaws of the employment programmes included: (i) the absence of a self-targeting mechanism to include informal workers, (ii) the duplication of functions and administration costs between the programmes because of the overlap in objectives and potential beneficiaries and (iii) the possibly low impact of the programmes in terms of the number of new jobs generated as a result of them, as distinct from the number of jobs financed by them (see Bravo, Contreras and Medrano, 2004; Guzmán, 2016).

\section{Institutional factors that affected the State's ability to scale up social protection programmes}

\section{Positive factors}

\section{(a) The public debt reduction of the 1990s as a self-protection mechanism}

Between 1989 and 1999, gross central government debt was reduced from 47\% to 14\% of GDP. This continuous decline in the public debt burden contributed in several ways to the maintenance of stable social spending growth after 1999 and thence to the scope for scaling up social protection programmes during the crisis. First, the reduction in debt meant a decrease in the resources needed to service it, with the direct result that more resources were available to be redirected to social areas. This has been called the "social dividend" of the fiscal policy (Ministry of Finance, 2004).

Secondly, keeping public debt low constitutes a self-protection mechanism for the country, since there is likely to be less need for severe fiscal adjustments in the event that interest rates rise sharply and capital flows behave procyclically in response to trade shocks. The continuous reduction of public debt during the upturn helped to build confidence in the long-term sustainability of the fiscal policy applied during the crisis. Furthermore, lowering public debt during upturns helps to ensure better external borrowing conditions during recessions (Arenas de Mesa and Guzmán, 2003). Indeed, the government carried out several sovereign bond operations during 1999-2002, raising more than US\$ 2 billion at lower spreads than the Latin America and Caribbean region generally. ${ }^{13}$ Chile had the lowest country risk rating in the region during the period, and its macroeconomic policies were positively evaluated in international competitiveness rankings (see, for example, World Economic Forum, 2004).

\section{(b) The Copper Revenue Stabilization Fund as a self-insurance mechanism}

The Copper Revenue Stabilization Fund (FEC) was created in 1985 to smooth fluctuations in fiscal revenues produced by changes in the copper price. Its main purpose is to save resources when the current price is above an estimated long-term price (called the reference price) so that these can be used when the current price is lower. In addition, the government has sometimes used the accumulated resources to prepay public debt. The fund is administered by the central bank, which is a safeguard against discretionary use, since that institution is independent of the central government. ${ }^{14}$

The FEC can be categorized as a country-level self-insurance mechanism that allows resources to be transferred from good to bad states to mitigate the effects of adverse terms-of-trade shocks. As figure 4 shows, when the stabilizing effects of the FEC scheme are stripped out, copper revenues fluctuate greatly each year. When net flows from the FEC are included, they vary much less.

\footnotetext{
${ }^{13}$ See Ministry of Finance (2002) for a discussion of this point.

${ }^{14}$ See Arellano (2005) for a detailed description of FEC operations and rules.
} 
Figure 4

Fiscal revenues from copper before (gross) and after (net) the operation of the Copper Revenue Stabilization Fund (FEC), 1987-2004

(Percentages of GDP)

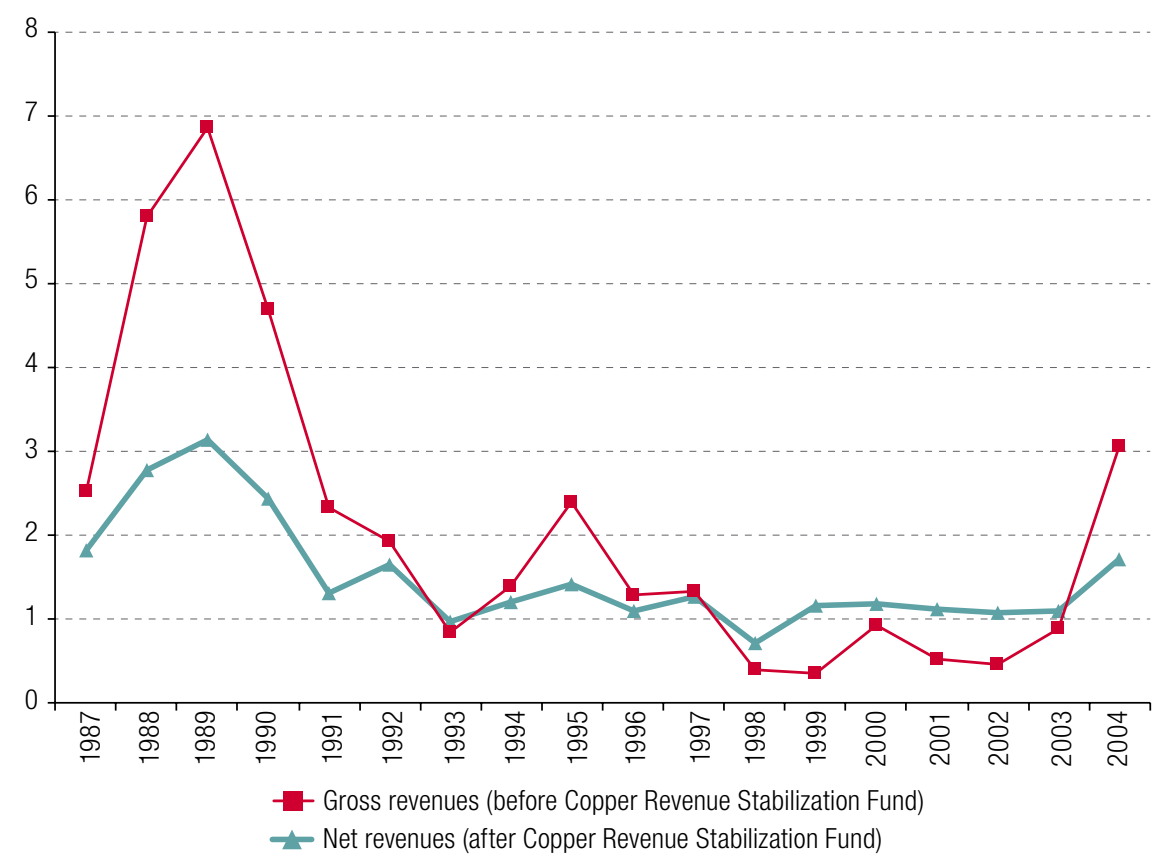

Source:J. P. Arellano, "Del déficit al superávit fiscal: razones para una transformación estructural en Chile", Serie Estudios Socio/Económicos, No. 25, Santiago, Economic Research Corporation for Latin America; and Treasury General of the Republic of Chile.

Before the creation of the FEC, public spending was likely to increase after a (transitory) rise in revenues, making it difficult to reduce expenditure in the event of a severe terms-of-trade shock. As in other Latin American and Caribbean economies, Chilean governments hitherto had commonly failed to provide for bad times by saving in good times and lacked a sufficiently diversified fiscal revenue base. The creation of the FEC, together with the fiscal rule explained below, helped to put fiscal expenditure growth on a more sustainable path, thus allowing fiscal policy to play a countercyclical role even during the 1999 downturn. The resources drawn from the FEC averaged US\$ 291 million a year during the 1999-2003 period and contributed directly (because of the extra revenues) and indirectly (because prepayments meant that fewer resources were needed to service the debt) to continuing social expenditure growth during this period.

\section{(c) The structural surplus rule as a self-insurance mechanism}

Since the 2001 budget, the government has incorporated into the stabilization mechanism not only copper price fluctuations but also variations in fiscal revenue caused by fluctuations in GDP growth relative to its long-term trend. This was introduced as an estimate of long-run trend structural revenues so that current expenditure could be calculated from a medium-term base. Thus, the structural balance reflects the amount of revenues and expenditures if the economy were operating at full potential and copper were trading at its medium-term price. ${ }^{15}$

\footnotetext{
15 The FEC system as explained in letter (b) is included in the fiscal rule. See Marcel and others (2001) and Ministry of Finance (2001) for a detailed description of the structural balance methodology and its rules of operation and Larraín and others (2011) for an analysis of more recent changes.
} 
This mechanism includes a self-imposed fiscal rule requiring a structural surplus whose level was initially set at $1 \%$ of GDP. This rule allows automatic budgetary stabilizers to operate fully without fine-tuning of fiscal policy at any phase of the cycle. It means that a countercyclical fiscal policy can be followed, since the expenditure path is determined by structural revenues. As a result, the variance of expenditure changes has decreased substantially. Figure 5 shows the results of its application during 1997-2005.

Figure 5

Actual and structural fiscal balances, 1997-2005

(Percentages of GDP)

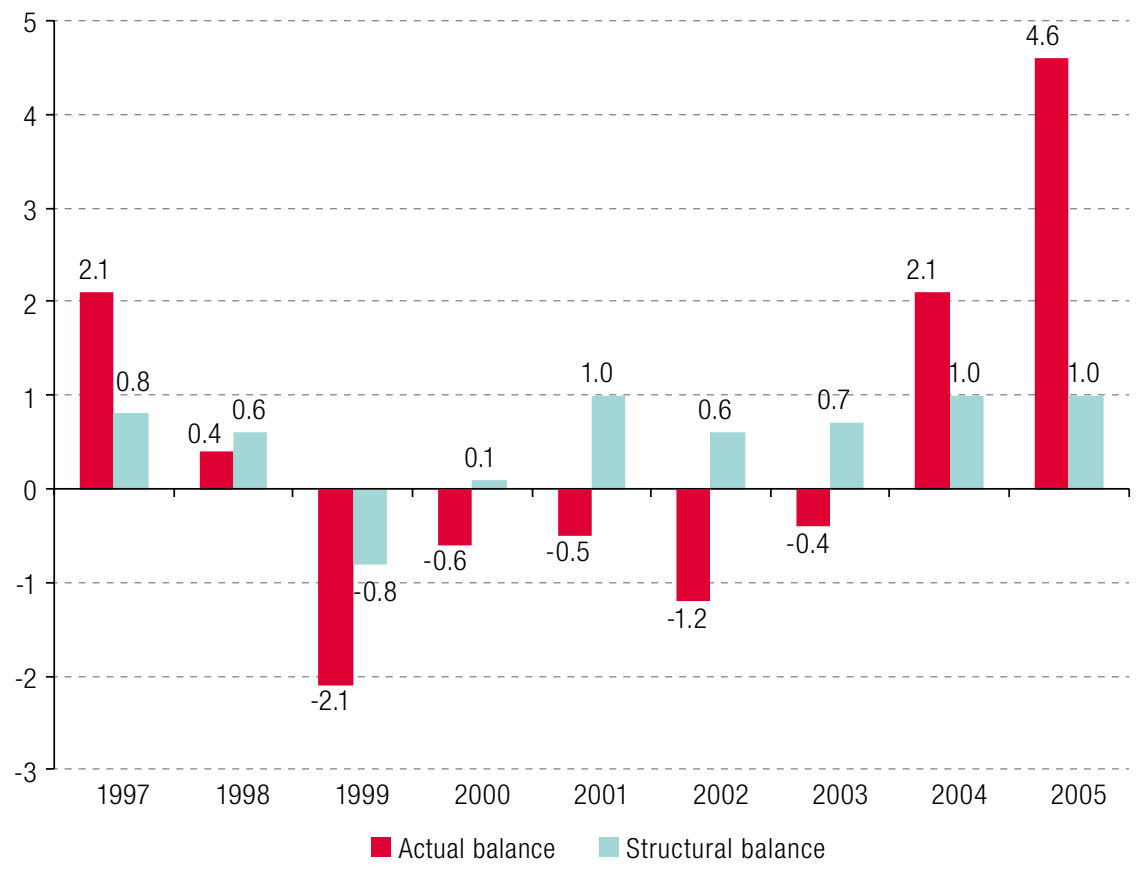

Source: Budgetary Affairs Bureau (2010).

According to Gill and llahi's (2000) classification, Chile's fiscal rule can be seen as a country-level self-insurance measure. Like a stabilization fund, it transfers resources from good to bad states. Furthermore, by pursuing long-term fiscal policy sustainability and giving a clear sign of fiscal discipline to the markets, the rule should operate as a self-protection mechanism, reducing the likelihood of financial contagion from crises affecting other countries in the region. Despite running current fiscal deficits during 2001-2003, Chile had some of the lowest sovereign bond spreads in the region, and correlation with other emerging market spreads fell. This is evidence that a credible and efficient fiscal rule can serve as a protection against macro risk (World Bank, 2005).

\section{(d) The new monetary, exchange-rate and fiscal policy mix}

Besides implementing the new fiscal rule, Chile moved to a new monetary, exchange-rate and fiscal policy mix. Since 1999, the main policy aim for the central bank has been to keep annual inflation in the range of $2 \%$ to $4 \%$. Also in 1999, exchange-rate policy shifted from a band scheme to a free float. Those measures were aimed at obtaining better protection against external shocks and greater monetary policy independence at a time of increasing integration into international financial markets. 
Application of the fiscal rule had major implications for the relationship between fiscal and monetary policy (Budgetary Affairs Bureau, 2000). As mentioned, the fiscal rule allows automatic budgetary stabilizers to operate fully without fiscal policy having to be fine-tuned to phases in the cycle. Given this, the preponderant short-term stabilization role is played by monetary policy, which, in combination with a completely flexible exchange-rate policy, can perform the function of controlling inflation and reducing the variability of output. The scheme therefore requires extensive coordination between fiscal and monetary policy, since the leeway for the monetary policy stabilization role depends on how well the fiscal rule is met.

This new policy framework has been remarkably effective since 2000. In particular, interest rates remained substantially low during the new negative phase of the cycle in 2001-2002. This allowed monetary policy to play a stabilization role via improved macroeconomic policy coordination. Thus, fiscal policy played a countercyclical role from 2000 but, by contrast with 1998-1999, this did not put the interest rate under extra greater pressure. The Chilean economy was thus undoubtedly left better placed to absorb the effects of future shocks.

Likewise, the central bank has shown its commitment to exchange-rate flexibility since the floating system was implemented in 1999, allowing the exchange rate to fluctuate in response to different shocks. The credibility of the floating regime has considerably decreased currency mismatches between assets and liabilities in the corporate sector and enhanced the role played by exchange-rate flexibility in helping the economy to adjust to external shocks (Claro and Soto, 2013).

\section{(e) Preparatory measures adopted by the central bank before implementing the freely floating exchange-rate system}

The adoption of a freely floating system in September 1999 was based on the assessment that the central bank had a sufficiently credible track record in controlling inflation, that hedge markets were more developed and that there were no serious currency mismatches in the private sector (Claro and Soto, 2013). As mentioned before, these positive conditions were mainly the result of the preparatory measures adopted by the central bank prior to floating.

A successful transition to a flexible exchange rate depends on the correct management of a number of institutional and operational issues. According to Duttagupta, Fernández and Karacadag (2005), the evidence shows that four things are usually needed: (i) a deep and liquid foreign exchange market, (ii) coherent central bank interventions in the foreign exchange market, (iii) an adequate alternative nominal anchor to replace the fixed exchange rate and (iv) effective management and supervision of both public and private sector exposure to exchange-rate risk.

In the light of these requirements, Ötker-Robe and others (2007) analyse the operational aspects of Chile's transition from a fixed to a floating regime in 1999. First, they argue that the foreign exchange market, including the spot and forward markets, developed steadily during the 1990s, as over time the authorities liberalized the regulations affecting arbitrage operations, authorized swap transactions, eased access to these markets and allowed greater exchange-rate flexibility within the crawling band. Likewise, in preparation for floating, in 1998-1999 the central bank introduced new exchange-rate hedging instruments in the form of dollar-indexed promissory notes (PRD), ${ }^{16}$ implemented new derivatives regulations covering futures trading in pesos and other currencies, among other things, and changed certain requirements to improve the currency matching of commercial bank transactions (Central Bank of Chile, 1998 and 1999). Thus, by 1999 the onshore spot, forward and swap markets and the offshore non-deliverable forward (NDF) market were all sufficiently developed (Ahumada and Selaive, 2007).

16 These notes were replaced by dollar-denominated central bank bonds (BCD) in 2002. 
Regarding the second requirement, coherent foreign-exchange market interventions, a government that wants to move towards a flexible regime needs to formulate policies on the objectives, timing and amounts of intervention (Duttagupta, Fernández and Karacadag, 2005). At the time the regime was changed, the authorities announced a new intervention strategy: the central bank indefinitely suspended its formal commitment to the exchange-rate band but retained the right to intervene in exceptional circumstances such as a sudden increase in exchange-rate volatility not justified by fundamentals (see Central Bank of Chile, 1999). As a result, the central bank has intervened a few times since 1999, notably in 2001 and 2002. The interventions have been transparent and preannounced, including details of the specific period during which the central bank might intervene and the maximum amounts to be committed (Ötker-Robe and others, 2007). Pre-announcement and the stipulation of a specific time period showed that the commitment to a fully floating regime was not at risk (Morandé and Tapia, 2002).

The third requirement was the replacement of the fixed exchange rate with an adequate alternative nominal anchor. During the 1990s, monetary policy was conducted by setting declining inflation targets that were explicitly announced each year and using the crawling exchange-rate band as the nominal anchor. When the band was abolished, the central bank announced a new inflation target from the end of 2000: annual inflation was to be held within the range of $2 \%$ to $4 \%$ (centred on $3 \%$ ) over a horizon longer than one year (24 months). Thus, a full-fledged inflation target was established with the abolition of the crawling band, and the inflation target became the sole anchor for inflation expectations under the fully floating system (Ötker-Robe and others, 2007). Additionally, in August 2001 the central bank switched from a real to a nominal policy interest rate. This was a natural step after exchange-rate liberalization and capital account opening, given the need to increase transparency in the conduct of monetary policy (Central Bank of Chile, 2001). Previously, the policy interest rate had been indexed to past inflation. This was useful when inflation was high and volatile, as in the 1980s. However, a real policy interest rate is difficult to handle in periods of low inflation and low or negative growth. At such times, the most appropriate policy may be to set a negative real interest rate, but while explicit negative real rates can be used for bank deposits, they cannot be used as a macroeconomic instrument. ${ }^{17}$ This change therefore widened the range of monetary policy options at a time when such options were progressively narrowing as a result of declining inflation (Fuentes and others, 2003).

The fourth element of the pre-float measures was the effective management and supervision of exchange-rate risk. During the 1990s, the exchange-rate band provided private agents with implicit currency risk insurance, which in turn created moral hazard. Private agents thus tended to take rather risky positions in the form of substantial net currency liabilities. Prior to floating, the central bank strengthened regulations on such net liabilities and on maturity and interest-rate imbalances. For the banking sector, in August 1998 the central bank retained the old currency exposure limit of 20\% of core capital, but the computation of mismatches distinguished between currencies (Cowan and De Gregorio, 2007). In 1999, currency mismatch regulations were revised to incorporate all foreign exchange operations, and new rules for managing liquidity and interest-rate risk were introduced. Derivative transactions were allowed, and the authorization requirement to engage in these transactions with external counterparties was abolished by 1999 (Ötker-Robe and others, 2007). The corporate sector had a prudent attitude towards the risk of currency mismatches even in the pre-float period (Cowan and De Gregorio, 2007), and the gradually widening crawling band probably provided a limited implicit guarantee to those holding unhedged foreign liabilities, thereby limiting unhedged exposures (De Gregorio and Tokman, 2005). Additionally, the forward market was already sufficiently developed, which facilitated management of foreign exchange risks.

\footnotetext{
17 I am grateful to an anonymous referee for raising this point.
} 


\section{Negative factors}

\section{(a) Absence of systematic interaction between programmes and duplication of functions and objectives}

The stable progress and financing of the social protection system helped to attenuate the impact of the 1999 downturn on poor households. However, it is likely that the lack of a more developed social protection system affected the scope for scaling up social protection programmes during the 1999 shock.

In particular, the lack of a common institutional framework and systematic interaction between public institutions undermined the efficiency of the employment programmes in terms of coverage and duplication of functions. The employment programmes had considerable overlaps in their objectives and potential beneficiaries, which caused duplication of functions and administration costs.

\section{(b) Inadequate installed administrative capacity before the crisis}

The inadequacy of installed administrative capacity before the crisis considerably complicated the task of setting up a public apparatus to respond rapidly to the urgent demands arising after it. Before long, though, a new set of public programmes was scaled up in response to the crisis. The coverage achieved by the programmes in a short time was actually quite remarkable, but this lack of administrative capacity stressed some public institutions, such as the National Training and Employment Service (SENCE) (Bravo, Contreras and Medrano, 2004), which found themselves having not only to deal with their regular programmes but to carry out new human resource relocation tasks, as well as achieving demanding coverage objectives for numbers of beneficiaries covered by the respective programmes each month.

\section{(c) Inertia in expenditures committed before the crisis}

The ability of institutions to scale up social protection programmes after the onset of the crisis was affected by the rigidity and inertia of a high proportion of fiscal expenditures. A large share of spending was already committed before the onset of the crisis as a result of permanent laws associated with extensive reforms initiated before it. This was the case, for instance, with the judicial and educational reforms initiated in the 1990s. Around $76 \%$ of public expenditures included in the 2000 budget were already committed before 2000 . This percentage breaks down as follows: (i) $66 \%$ of total expenditures already committed as a result of permanent laws on pensions, subsidies and pay for public sector employees and (ii) $10 \%$ of total expenditures already committed to delayed investment outlays for projects launched in previous years. Only $24 \%$ of the total expenditures in the 2000 budget were not already committed (discretionary expenditure).

In consequence, the increase in resources needed to scale up the programmes was secured in part by reducing discretionary expenditures (i.e. expenditures not previously committed). This delayed some new initiatives not related to the employment programmes and reduced the scope for increasing expenditure on contingency programmes.

It could thus be argued that there were trade-offs between scaling up the employment programmes yet further and honouring commitments relating to reforms already initiated before the crisis (such as the judicial and educational reforms) and new reforms launched after 2000 (such as the health-care reform). 


\section{Concluding remarks}

Chilean social protection policies have been through a learning process as a result of several macroeconomic shocks. In particular, the 1982-1983 debt crisis, the 1997-1998 Asian crisis and the Great Recession of 2008 have influenced the macroeconomic policies and economic reforms implemented in Chile during the past decades.

Against this background, the present article is meant to provide an introduction to the Chilean experience of coping with the 1999 recession by analysing how some of the policies adopted at the time have enabled strong social spending growth to be reconciled with a balanced fiscal policy. The Chilean experience could serve as a starting point for exploring innovative social protection solutions in other Latin American countries, with a view to making long-term social investments and medium-term fiscal consolidation mutually supportive and sustainable.

This article argues that the adjustment policy adopted in 1997-1998 can be considered inappropriate with hindsight. The lack of coordination between the fiscal and monetary policies adopted during that period aggravated the effects of the initial external shocks faced by Chile (namely reduced capital inflows, worsening terms of trade and contagion from other countries' crises). The 1998 illiquidity episode caused the economy to contract by more than was necessary. This severely affected the investment and consumption decisions of the private sector and had prolonged effects on unemployment.

Even though the macroeconomic policies adopted during the recession were inappropriate, the fiscal discipline and strong public institutions developed before and after it improved Chile's social protection policies. Specifically, the public debt reduction of the 1990s, the Copper Revenue Stabilization Fund created in 1985, the adoption of the structural surplus rule of 1\% of GDP in 2000 and the new monetary, exchange-rate and fiscal policy mix adopted since the recession have reduced or mitigated the risk of new upheavals and hence the vulnerability of the Chilean economy to these. As a result, Chile was able to implement a countercyclical fiscal policy during 2000-2003 and the Great Recession.

This paper identifies three main issues that affected the scope for scaling up social protection programmes during the 1999 recession. First, this was limited by the absence of systematic interaction between programmes and duplication of functions and objectives. Second, inadequate installed administrative capacity before the crisis constrained the government's choices and ability to expand multiple employment programmes with common objectives and overlaps in potential beneficiaries. Lastly, the inertia of expenditures committed before the recession was a factor that limited the potential for increasing the resources given to contingency programmes.

The Chilean development strategies adopted during the past decades have been successful in terms of economic growth and poverty alleviation. However, large steps still need to be taken to validate them as an effective development model for delivering real social protection and promoting inclusive and more egalitarian long-run growth. To become a role model for other Latin American countries, the Chilean development system should consistently achieve success both in economic growth and in the way this is distributed among citizens (Ffrench-Davis, 2014).

It is therefore critical for Chile to implement high-quality structural reforms combining economic growth, political stability and innovative strategies. These reforms should be based on past achievements but also on the accumulated experience from previous macroeconomic shocks. This paper has sought to draw attention to that accumulated experience so that it is considered in the design of policy reforms and so that cross-country lessons are shared. 


\section{Bibliography}

Ahumada, L. A. and J. Selaive (2007), "Desarrollo del mercado de derivados cambiarios en Chile", Revista de Análisis Económico, vol. 22, No. 1.

Arellano, J. P. (2005), "Del déficit al superávit fiscal: razones para una transformación estructural en Chile", Serie Estudios Socio/Económicos, No. 25, Santiago, Economic Research Corporation for Latin America.

Arenas de Mesa, A. and J. Guzmán (2003), "Fiscal policy and protection in Chile", CEPAL Review, No. 81, Santiago, Economic Commission for Latin America and the Caribbean (ECLAC).

Atria, F. (2014), Derechos sociales y educación: un nuevo paradigma de lo público, Santiago, LOM Ediciones.

Atria, F. and others (2013), El otro modelo: del orden neoliberal al régimen de lo público, Santiago, Debate.

Bravo, D., C. Contreras and P. Medrano (2004), "Informe final. Evaluación de impacto: programas de empleo con apoyo fiscal", Santiago, University of Chile [online] www.dipres.cl.

Budgetary Affairs Bureau (2000), "Aspectos macroeconómicos del proyecto de ley de presupuestos del sector público del año 2001” [online] http://www.dipres.gob.cl/597/articles-37473_doc_pdf.pdf.

- (1999), "Aspectos macroeconómicos del proyecto de ley de presupuestos del sector público del año 2000" [online] http://www.dipres.gob.cl/598/articles-37476_doc_pdf.pdf.

Calvo, G. and C. Reinhart (2002), "Fear of floating", The Quarterly Journal of Economics, vol. 117, No. 2, Oxford, Oxford University Press.

Central Bank of Chile (2001), Informe de politica monetaria, Santiago. (1999), Memoria anual 1999, Santiago. (1998), Memoria anual 1998, Santiago.

Claro, S. and C. Soto (2013), "Exchange rate policy and exchange rate interventions: the Chilean experience", BIS Papers, No. 73, Bank for International Settlements [online] https://www.bis.org/publ/bppdf/bispap73.pdf.

Contreras, D. (2009), "Poverty, inequality and welfare in a rapid growth economy: the Chilean experience", The Poorest and the Hungry: Assessments, Analyses, and Action, J. von Braun, R. Vargas Hill and R. Pandya-Lorch (eds.), Washington, D.C., International Food Policy Research Institute (IFPRI).

Corbo, V. and J. Tessada (2003), "Growth and adjustment in Chile: a look at the 1990s", Working Paper, No. 204, Santiago, Central Bank of Chile.

Cowan, K. and J. de Gregorio (2007), "International borrowing, capital controls, and the exchange rate: lessons from Chile", Capital Controls and Capital Flows in Emerging Economies: Policies, Practices and Consequences, Cambridge, Massachusetts, National Bureau of Economic Research.

De Ferranti, D. and others (2000), Securing Our Future in a Global Economy, Washington, D.C., World Bank.

De Gregorio, J. (2005), "Crecimiento económico en Chile: evidencia, fuentes y perspectivas", Estudios Públicos, No. 98, Santiago, Centre for Public Studies.

De Gregorio, J. and A. Tokman (2005), "El miedo a flotar y la política cambiaria en Chile", Economía Chilena, vol. 8, No. 3, Santiago, Central Bank of Chile.

Duttagupta, R., G. Fernández and C. Karacadag (2005), "Moving to a flexible exchange rate: how, when, and how fast?", Economic Issues, No. 38, Washington, D.C., International Monetary Fund (IMF).

Ffrench-Davis, R. (2014), "Is Chile a model for economic development?", Serie de Documentos de Trabajo, No. 392, Santiago, University of Chile.

Ffrench-Davis, R. and J. L. Machinea (2007), Economic Growth with Equity: Challenges for Latin America, Santiago, Economic Commission for Latin America and the Caribbean (ECLAC).

Fuentes, R. and others (2003), "Efectos de la nominalización de la política monetaria en Chile", Working Paper, No. 197, Santiago, Central Bank of Chile.

Gill, I. and N. Ilahi (2000), "Economic insecurity, individual behavior, and social policy", Working Document, No. 31522, Washington, D.C., World Bank.

Guzmán, J. (2016), "Social protection during recessions: evidence from Chile", Journal of Economic Policy Reform, vol. 19, No. 4, Taylor \& Francis.

Larraín, F. and others (2011), "Una política fiscal de balance estructural de segunda generación para Chile", Estudios de Finanzas Públicas, Santiago, Ministry of Finance.

Marcel, M. and others (2001), "Balance estructural del gobierno central: metodología y estimaciones para Chile: 1987-2000", Estudio de Finanzas Públicas, Santiago.

Mayol, A. (2012), El derrumbe del modelo: la crisis de la economía de mercado en el Chile contemporáneo, Santiago, LOM Ediciones. 
Ministry of Finance (2004), "Exposición sobre el estado de la hacienda pública 2004", Santiago.

(2002), "Exposición sobre el estado de la hacienda pública 2002", Santiago.

_ (2001), "Exposición sobre el estado de la hacienda pública 2001", Santiago.

Morandé, F. and M. Tapia (2002), "Exchange rate policy in Chile: from the band to floating and beyond", Working Paper, No. 152, Santiago, Central Bank of Chile.

OECD (Organization for Economic Cooperation and Development) (2015), OECD Economic Surveys: Chile 2005, Paris.

Ötker-Robe, I. and others (2007), "Moving to greater exchange rate flexibility: operational aspects based on lessons from detailed country experiences", Occasional Paper, No. 256, Washington, D.C., International Monetary Fund (IMF).

World Bank (2005), Household Risk Management and Social Protection in Chile, Washington, D.C.

World Economic Forum (2004), "Executive summary", Geneva. 
